\title{
British Guiana: A sketch
}

\section{Sir David P. Chalmers}

To cite this article: Sir David P. Chalmers (1896) British Guiana: A sketch, Scottish Geographical Magazine, 12:3, 125-139, DOI: 10.1080/00369229608732861

To link to this article: http://dx.doi.org/10.1080/00369229608732861

册 Published online: 27 Feb 2008.

Submit your article to this journal $\pi$

III Article views: 4

Q View related articles $₫$ 


\section{BRITISH GUIANA :}

\section{A Sketch.}

By Sir David P. Chalmers, recently Chief Justice of British Guiana.

(Read before the Society on Jan. 30th, 1896.)

I FEEL considerable diffidence in appearing before a Geographical Society, as I cannot claim the qualifications of a discoverer or explorer of unknown regions. I stated these difficulties to your very courteous Secretary when he did me the honour of conveying to me the wish of your Council that I should read a paper, and his reply, after referring to 6 the Council, was to the effect that my objection had been overruled. I o shall therefore proceed to put before you some particulars about our N colony of British Guiana, which I hope may at the present time have $\Xi$ some interest for you.

Long before Great Britain possessed any colony in South America, the whole country lying along the Atlantic seaboard on the north$\rightarrow$ eastern shoulder of that continent, between the two great rivers the - Orinoco and Amazon, and bounded inland by what were then Spanish $\approx$ provinces-Grenada and New Andalusia_was known by the general name of Guiana, derived, it is believed, from the Indian name of a small I river, the Wa-ini or Gwa-ini, which enters the Atlantic near the mouth $\Phi$ of the Orinoco. Towards the middle of the fifteenth century, small $\checkmark$ Dutch trading ships began to visit the West Indies. Some of them sailed along the coasts of the mainland, which lay immediately to the south of the islands, and opened trade with the aboriginal inhabitants, bartering knives, axes, beads, and the like, for cotton and other products B of the country. As early as 1580 these voyagers had established a trading post at the mouth of the Pomeroon, and another on the Abary a river, both within what is now our colony of British Guiana. In 1595, D that chivalrous and adventurous Englishman, Sir Walter Raleigh, set sail Fin his own ship, accompanied by two smaller ones, in search of "that mighty rich and beautiful empire of Guiana, and of that great and golden city which the Spaniards call El Dorado and the Indians Manoa." He explored part of the Orinoco, and, after various adventures, returned to England, bringing back a most glowing account of the wealth and resources of the country, its mines of gold and precious stones, and the "Imperial City of El Dorado." During the evil times that fell upon Raleigh after this, and in his long imprisonment, he still cherished dreams of Guiana and the Golden City, and when at length he was released, he again led an expedition to the land of hope. But this expedition resulted in disastrous failure, and the English Crown obtained no dominion in Guiana at that time. In the early part of the last century, the Portuguese, French, and Dutch claimed sovereignty over different portions of this country. The Dutch held the northern part, extending from the mouth of the Orinoco south-eastwards to the river Maroni, a distance of about 530 miles. The French possessions extended 
from the Maroni south to Cape Orange, a distance of somewhat over 200 miles. The Portuguese held the remainder of the country as far as the mouth of the river Amazon. But the representatives of the several nationalities had only made actual settlements in some places on the coast, from whence they exercised a more or less widely extended influence over the Indians, who were the real inhabitants of the country, and at the time of which I am speaking far outnumbered the strangers.

The colony which we know as British Guiana was settled by the Dutch as three colonies, named from the three rivers upon which the first beginnings of occupancy took place, the colony of Essequebo, the colony of Demerara, and the colony of Berbice. In order the better to understand the position, political as well as economical, of our colony, it is necessary to carry our view backwards a little to the times of the Dutch settlers. It was they who rendered it possible for us to utilise those amazingly fertile lowlands which form the sugar-producing portions of the colony. "Every acre," it has been well said, "has been the scene of a struggle with the sea in front and the floods behind"; and the whole system of embankments, canals, and sluices, to which we owe the safety from inundation, and the possibility of cultivating our coast and riverside lands, is due to Dutch skill, industry, and perseverance. The first beginnings of trade were indeed very small. Early in the seventeenth century the principal post in the colony of Essequebo was on an island called in Dutch, Kyk-over-al-literally, see-over all-situated about fifty miles from the sea, in a tributary of the Essequebo river. At this time one ship in a year was sufficient to carry on the whole trade between the colony of Essequebo and the mother country. Gradually the cultivation of the land made progress, and contemporaneously the trade over sea increased, so that when we come down as late as 1791, we find that the whole of the coast lands, from the mouth of the Essequebo river as far north as the mouth of the Pomeroon, had been granted out, and were being cultivated as plantations. The settlement of the colonies of Demerara and Berbice, somewhat later in date, was on very similar lines with that of Essequebo. The first settlements were made by traders, and these settlements were followed by appropriation for cultivation of the lands lying along the seacoasts and river banks.

The colonies met with many vicissitudes in their earlier growth, and they suffered in the wars. In 1781 they capitulated to the British. In 1782 the British admiral in the West Indies, having to cope with the Americans, French, Dutch, and Spaniards, had his hands too full to garrison the colonies in Guiana sufficiently, and they surrendered to a greatly stronger French force. In 1783 they were given back at the peace to the Dutch, but surrendered to the British in 1796. In 1802, at the Peace of Amiens, they were again given back to the Dutch, but again surrendered to Great Britain in 1803, and have been British possessions continuously since then, and the rights of Great Britain were fully recognised in the treaty arrangements made at the Peace of 1814.

The coastline of the present colony of British Guiana-or rather perhaps I should say, that which we claim as British Guiana-extends in a south-easterly direction from the mouth of the Amakura river 
in the estuary of the Orinoco in N. latitude about $8^{\circ} 75^{\prime}$ to the mouth of the river Corentyn, which separates British Guiana from that part of the Dutch colonies still retained by them under the name of Dutch Guiana. Leaving the coast at this point, the boundary follows the course of the Corentyn in a southerly direction until it reaches a point about $1^{\circ} 50^{\prime}$ of $\mathrm{N}$. latitude. Then it proceeds south-west along the borders of Brazil, following the line of the Acarai mountains until it reaches to about $75^{\prime}$ of $\mathrm{N}$. latitude, which is its extreme southern point, and from thence the boundary follows a north-westerly direction, bordering at first with Brazil and then with Venezuela. It coincides for part of the way with the Takutu and Cotinga rivers, until the mountain Roraima is reached, and then it is said to proceed northeast to the Imataca range and onward in a northerly direction to the Amakura river, and to follow this river to the Orinoco. The Brazilian, as well as the Venezuelan, boundary has not yet been definitely settled. Our coastline is somewhat over 300 miles in length, not following the indenta$\cong$ tions and prominences closely; the greatest depth of inland measurement in a straight line from north to south is about 550 miles, and the greatest 6 breadth from east to west somewhat over 300 miles, but the average $M$ is considerably less, the outline on the Venezuelan and Brazilian sides $\ddot{\sigma}$ being irregular. These measurements are taken from a map recently published by Stanford, and probably vary a little from the measurements which may be made on some other maps. The superficial area is computed as being about 109,000 square miles, which is more than 4 the area of England, Wales, and Scotland taken together. So far, therefore, as territorial extent is concerned, this, the only British Dossession on the continent of South America, is no insignificant one.

The journey to Guiana is not difficult. Starting from Southampton, a run of eleven and a half days across the Atlantic in a direction south-west by south, or nearly so, would carry us to Barbadoes, which lies somewhat to the north and west of Guiana, and after a short a delay there for transhipment to an inter-colonial steamboat, a course of rather less than two days' further steaming would bring us to Georgetown, the principal town of the colony. The impression of Guiana which a voyager receives on approaching it is not very favourable. Long before coming in sight of land we observe a change in the colour of the water on which we are sailing. The deep transparent blue of the Atlantic, which is so beautiful a feature for the last five or six days previous to reaching Barbadoes, is no longer seen; the water seems shallower and much less bright. When we reach within forty or fifty miles of Guiana, there is a still greater change. We come to a rippling line in the water, as when two currents meet, but are slow to mingle, and on the further side of the line the water appears nearly opaque and of a brownish. yellow colour. The rippling line is not always seen, and then the change from clear to opaque takes place more gradually. This discoloration is produced by immense quantities of fine sand and débris of decayed vegetation which is brought down by the rivers of Guiana, and also by the greater rivers the Amazon and Orinoco, and is continually kept in motion by the currents which are always flowing over the shelving coast 
of this part of South America. The position of Georgetown is made out by means of a floating beacon or light-ship, which is also a pilot station, moored ten or twelve miles from the shore. At this distance the land seems perfectly level, and would be barely discernible except for tall chimney-stalks appearing on the horizon, which show the locality of some sugar manufactories. A little nearer, the feathery tops of palm-trees catch the eye, and then the features of the land we are approaching become more distinct. Wide expanses of vivid green mark the position of sugar-cane fields; white painted walls and roofs of houses show amongst groves of palms and other trees, and in a very short time after leaving the light-ship we run into the Demerara river, which forms an excellent natural harbour a mile and a half in width, in which a multitude of ships can find safe anchorage. Landing at one of the numerous jetties in the river-or stellings, as they are still called, according to the old Dutch nomenclature-we find ourselves in a city laid out in wide streets running north and south, and east and west, which intersect each other at right angles, forming rectangular blocks of moderate dimensions. These streets give free access to the breezes, which blow with much regularity. In many of them shady trees afford a shelter from the too predominant sunshine. In some streets are broad canals, reminding us even now of the Dutch founders. These canals serve a useful purpose in rapidly carrying off the superfluous water during rainy weather. Pink lotus flowers, and a hyacinth-coloured water-lily floating in these water-courses give variety to the colouring, and the giant leaves and flowers of the Victoria regia are seen in many places. Private dwelling-houses are of all sorts and sizes, without the slightest architectural pretensions, but following regular lines along the streets. Each stands in a plot of garden-ground, most of them bright with flowers and shaded with trees, and larger or smaller according to the means and inclinations of the owners. Among the conspicuous buildings is Queen's College, a Government foundation which does exceedingly good educational work. At the end of the same street is the Cathedral of the Diocese of Guiana. The original building has been removed and replaced by a much larger one, built of timber and concrete, one of the largest. -I am not sure that it is not quite the largest-structures of the kind which has ever been built. St. Andrew's Church is the principal Scotch church in Georgetown. It is a somewhat curious feature in the ecclesiastical settlement in Guiana that, although the colony as a whole is a bishop's see, under the jurisdiction of the Archbishop of Canterbury, the Scotch Church is not only concurrently endowed with the Anglican, but has also a territorial status; Anglican and Presbyterian parishes alternate throughout the colony, each parish lying contiguous on either side to parishes of a different denomination. I believe this arrangement has not led to any friction. Roman Catholic and Wesleyan churches are also assisted by grants of public money. The offices of the various Government departments are located in a brick and concrete structure-one of the few of the kind in Georgetown. The building material is mainly wood, both on account of the scarcity and expense of other material, and of the difficulty of making sufficient foundations in the 
soft and yielding subsoil for brick or stone buildings. We may also notice Water Street, the principal business street in Georgetown, and the Sea Wall, important as a bulwark against possible incursions of the sea and also as a promenade. Time does not permit us to linger in Georgetown; but I may tell you before leaving it, that it is a town of somewhat over 50,000 inhabitants, that it is the seat of government, the principal port for imports and exports, that it is governed by a Mayor and Corporation, that it contains several churches besides those I have mentioned, a town hall, an hospital capable of accommodating 700 patients, courts of justice, schools, alms-houses, a Royal Agricultural and Commercial Society, possessing an excellent library and museum, a Chamber of Commerce, an Institute of Mines, two Banks having the privilege of issuing their own notes, and was lighted by electric light four years before Edinburgh began to resort to this method of lighting. There is a large and well-managed Botanic Garden, which not only \& serves purposes of amenity and beauty, but also important economic $\Xi$ uses in the assistance it gives to agriculture, both by supplying plants $\sigma$ and seeds of the most approved descriptions, and by devising by experiments new methods of culture.

It would be a very incorrect idea of British Guiana if we were to think of it, as a dweller in Georgetown might perhaps be apt to do, as merely a level tract of seaboard and riverside land, mostly occupied with highly cultivated cane-fields and sugar manufactories. The flat belt in which the cane cultivation occurs occupies only a small portion of the colony. It varies in width from a few miles in some places to about forty or fifty miles in others. It is an alluvial deposit of great depth, resting upon granite. It is so thoroughly alluvial, consisting of clay and vegetable debris and perhaps a little sand, that it yields no stones large enough for road making; such roads as exist are made of burned clay and shells mixed together, and in some places of granite brought by water carriage from higher ground on the rivers. This flat land slopes very gradually upward as we go inland; it is generally bounded by a row of low sandhills, and beyond these we enter upon a wide uncultivated region. The general elevation here is above that of the alluvial belt, but parts are low and swampy. Within this region a profitable trade has been carried on in timber, and it has been partially denuded in those parts which lie within easy distance of ports of shipment, and adjacent to the banks of rivers and creeks, where the indispensable aid of water carriage is available. In places remote from this means of transport immense breadths of forests remain untouched. The soil and climate are so fertile that wherever the large trees are cut down a thicket speedily springs up, almost impenetrable in its density, composed of smaller trees, shrubs, and creepers. In process of time the trees of stronger growth may overcome the weaker undergrowth and become valuable timber trees, but as yet there is no systematic forestry. Beyond, and at a higher level than this first forest region, there are huge tracts of primeval forest. These tracts are above the cataracts, which are met with on all the great rivers at varying distances from the sea, these cataracts being in fact the sudden descent of the rivers from the

vou, XII. 
higher inland plateau. The last region, and the farthest from the sea, is that of the savannahs. It is continuous with the grass-covered plains so frequent in the central parts of South America. The general appearance of the savannahs is not unlike those wider parts of the English downs, where the rolling surface is broken by a few stunted hawthorns or clumps of tall furze. But in the hollows between the ridges of the savannahs, instead of the fir, beech, and hazel coppices of our own country, there are groves or clumps of Eta palms, or other tropical trees, or shrubs. The principal mountains of the colony are found in the savannah region. The term savannah is also applied to a variety of grassy plains, more or less marshy, met with near the creeks and rivers in the forest region, and even descending to the seaboard. The aspect of some of these lower savannahs I was very familiar with in travelling on the road between Georgetown and New Amsterdam for the purpose of holding the circuit court at the latter place. The road ran through a perfectly level plain, stretching for many miles, bordered on the one side by a belt of mangrove and courida trees fringing the seashore, and on the other by the trees of the forest region. The plain was covered in rainy weather with tall rank grass and other plants, much frequented by stork-like birds, the most conspicuous of which was the Negrokop, a bird of dark grey plumage, standing almost four feet high; he would stalk along with majestic strides, ever and anon bending his. long neck to pounce upon the smaller animals on which he fed; sometimes these birds were seen also in flocks. Alligators used to be seen in the watercourses bordering the road, but as they are timid animals, always hiding themselves when they can, those seen gave no adequate representation of the real numbers. Although in droughts these savannahs became very parched, and the herbage almost disappeared, they were much used for the pasturing of cattle, and great herds grazed on them. In the rainy weather so much water lay on the surface that it was not uncommon to see cattle up to their necks in water, suffering no inconvenience apparently, but busily cropping the succulent grasses and other herbage which rose above the surface. The most eastern portion of the colony does not show so distinctly the sort of terrace-like structure found in the central part. It is an inclined plain descending gradually from a height of about 800 feet to the sea-level. The plain extends westwards and southwards and connects with the savannahs of Brazil.

The only one of these regions in which any considerable number of inhabitants are found is the alluvial belt next the coast. Small parties of woodcutters visit the forests, and live there for weeks or months, but their residence only lasts until their work is accomplished. Since about 1884 it has been found that gold could be profitably worked in various places in the interior, and considerable numbers have betaken themselves to this attractive form of industry; but these gold-seekers and gold-diggers are companies of adventurers having no settled homes where they work, and, like the woodcutters, they return from time to time to their permanent dwelling-places in the coast region. The regions of primeval forest and savannah, so far as they can be said to be inhabited, are inhabited only 
by the Indians, and possibly a very small number of settlers. The Indians live widely apart, and moreover change their places of residence from time to time, even going over into Brazil or Venezuela, so that it has been difficult to form any close estimate of their numbers; but authorities most capable of judging have put the total number usually in Guiana as from 12,000 to 20,000 , the latter estimate being probably nearer the truth. These Indians are of different tribes, known by different names, and distinguished by considerable differences in their physical appearance and in their habits, but there seems no doubt that they all belong to the great race forming the aboriginal inhabitants of America. It would take too long to dwell upon the interesting questions connected with the Indians. The population of the colony, apart from Indians, was estimated in 1892 to consist of 141,531 Negroes and halfocastes, 105,463 East Indians, 3714 Chinese, and 12,166 Portuguese and Dnatives of Madeira and the Azores. The Europeans are only a small number, probably not more than 2000 in all. Their real number could Enot be ascertained by a census of the usual kind, as they are never all in the colony at any one time. The nationalities represented are English, French, German, Dutch, Irish, and Scotch.

Viewing our colony thus generally, as a land of wide forests and Osavannahs, the rivers are an important feature. They are not only the \#drainage channels which carry the superfluous rain-water to the sea, but Falso the highways leading from the inhabited parts into the interior. DThere is a good road along a portion of the sea-coast, about 120 miles -in all, and also extending a few miles inland from the mouths of the Demerara, Essequebo, and Berbice rivers; but with these exceptions there are no roads. The traveller who would visit the interior must take Whis way on the rivers and their tributary creeks and then through the forests. It is not always that he can find a path where he needs it. The axe and the felling knife are essential. He must be prepared often to cut his own path through the thick bush or jungle. Perhaps I should mention here-lest I would be representing the colony as less advanced Ethan it really is-that there is a railway, about twenty-one miles in Flength, running parallel to the coast road out of Georgetown, serving an important sugar district, and paying, I believe, good dividends, and that owhen I left Guiana there were other railway schemes under consideration. Ancluding the river Corentyn, a splendid river, navigable for 150 miles, which, as.I have already mentioned, is the boundary between British and Dutch Guiana, our colony is drained by five great rivers and six or seven smaller ones, not including tributaries or small streams. Taking these rivers in their order from north to south, the next to the Corentyn is the Berbice,navigable for ships of light draft for 150 miles, and having a total course of about 300 miles. The Demerara is navigable for eighty-five miles, and its entire course is about 200 miles. The Essequebo, although the largest of the rivers, has the shortest navigable course, being interrupted by cataracts at about sixty miles from the sea; it rises in the most southern part of the colony, and reaches the sea after a course of about 600 miles. Its estuary is twenty miles wide at its widest part. In this estuary are situated three large islands; one of them is twelve miles long by three miles 
across. Numerous other islands, some large, some small, said to equal in number the days of the year, are scattered along the course of this river. It has three very large tributaries: the Mazaruni, which rises in the near neighbourhood of Mount Roraima, and has a course of 200 miles before joining the Essequebo ; another, the Cuyuni, a familiar name in the boundary dispute, rises on the borders of Venezuela, and forms, for about 140 miles, the boundary between territory which is claimed as indisputably belonging to Great Britain, and other territory the title to which is considered doubtful. Its course, until it joins the Essequebo, is not much short of 300 miles. The third large tributary, the Rupununi, has a course of 220 miles. These great rivers all run nearly parallel to each other from south to north, and all enter the ocean in a direction oblique to the coast. Smaller rivers are the Canje, an affluent of the Berbice, having great depth of water, and running almost a level course for 150 miles; the Abary, Mahaicoay, and Mahaica creeks, running into the Atlantic between the Berbice and Demerara rivers, and the Pomeroon, Wa-ini and Barama falling into the Atlantic to the northward of the Essequebo. The Barima, navigable for at least eighty miles, and the Amakura, which is one of the boundary rivers, join the estuary of the Orinoco.

The rainfall in Guiana is very large, being on an average nearly 100 inches in the year at those stations on the coast where registers have been kept, and probably a good deal more in the interior, and it is a natural result that the flow of fresh water in the rivers during the rainy season is enormous. I have myself observed it in the Demerara and in the Berbice rivers (with which $I$ happen to be most familiar) running with the rapidity of a mill race. In the Demerara river it is estimated to run at ebb-tide seven or eight knots an hour in the rainy season. This current makes it a work of some difficulty and risk to go alongside ships in the larbour, and has sometimes led to serious accidents. I have already alluded to the quantity of detritus brought down to the sea by the river floods. A result of this and of the very shallow and shelving slope of the coast is the formation of banks not only at the river mouths, where they are a serious hindrance to navigation, but more or less all along the shores. These deposits frequently shift with the shifting of the currents. At one time there will be a secure rampart protecting the low-lying land from the inroads of the sea, and again, after some months, perhaps, the rampart will be washed away and breaches even made in the land behind. The necessity of protecting by artificial ramparts the coasts of the plantations forms one of the anxieties and a fertile source of expense in carrying on a sugar plantation. And not only must the plantation be protected from the sea in front, but also from the flood-water coming from the direction of the forest behind. Ramparts or dams all round the plantation, and trenches to carry away the masses of rain-water, are essential.

The character of the scenery of the rivers is, of course, very different. when above the influence of the tides from what it is in the lower reaches. Mangroves, with their strange aerial roots, fringe the banks where the salt water is a predominating influence. But even in the tidal waters 
the scenery is often of great beauty. The effect in sailing over these waters is as if passing through a series of lakes. Where the woodcutter has not too recently disturbed the landscape, the waters are bordered by a dense thicket of huge trees of varied forms and leafage, the brilliant blue sky is reflected in the almost still waters, the intense sunlight brings out the keenest contrasts of light and shade. "Going inland, the rivers are narrower and more picturesque. Being nearer, the forms of the vegetation can be better seen and are more appreciated; rocks and islands diversify the scenery. Cataracts occur on all, or nearly all, the rivers at a certain distance from the coast; the exceptions are those which have their course in the delta of the Orinoco. Lovers of Nature would find endless enjoyment in studying the varying picturesque aspects of the cataracts. Persons engaged in such occupaGions as wood-cutting or gold-seeking look upon them as so many Dbstructions to navigation, which no doubt they are. Unfortunately gany of the cataracts are associated with disastrous boat or canoe g्gidents.

The fall which is perhaps best known by name is the Kaieteur. The hame is derived from an Indian tradition, which narrates how an old man, Thaving become troublesome to his family beyond what they considered Could reasonably be borne, was placed by them in a small canoe set adrift in the river a little above the fall, over which it was, of comse, gुpeedily carried. The canoe itself, the tradition says, was changed into ointed rock, which is still seen at the fall, and the basket-work portmanteau, or peggall, in which the family had considerately packed the old anan's belongings, became a square rock, also still seen. It illustrates the innexplored character of Guiana that this fall, which occurs on the Potaro, a large tributary of the well-known Essequebo, was unknown .except to the Indians until 24th April 1870, when it was first seen by Mr. Barrington Brown; and when Mr. Brown made his discovery known In Georgetown, great surprise was manifested, and almost doubts were raised. I quote a few sentences written by Mr. Brown on the first freshgless of the discovery :- "We came within the roar of a large fall. I gobserved that heavy masses of vapour were drifting before the north-east Grind, making the trees, grass, and shrubs on our right dripping wet. This came from the great fall to which we were in close proximity, but which Aras hidden by a grove of trees. Making a detour to our right through the grove, we came on the flat rocks at the head of the fall, and walking to the edge of the precipice, down which the water was precipated, I gazed with wonder and delight at the singular and magnificent sight that lay before me. Not being prepared for anything so grand and startling, I could not at first believe my eyes, but felt that it was all a dream. There, however, was the dark silent water, passing slowly but surely to the brink of a great precipice, and breaking into ripples as it approached its doom; then, curving over the edge in a smooth mass of a brownish tinge, changing into a snow-white fleecy foam, it was precipitated downwards into a black seething caldron hundreds of feet below. Of how many hundreds I could not with certainty make out; but, judging from the appearance of the river below the basin, I thought it must be 
near upon 900 feet. ... The river was swollen by the late rains, and was over 100 yards in width, containing a vast volume of water, which, as it reached the basin below, sent up great creamy spirts of foam with a steady thundering roar." Subsequent accurate measurements showed the first estimate to be not far from correct. The river makes one perpendicular leap of 741 feet, and then falls by a sloping cataract 88 feet further. The perpendicular leap is thus almost exactly seven times the height of the Dean Bridge, at Edinburgh, which, I think, is 106 feet above the bed of the river.

The forest trees resemble our own Spanish chestnuts, oaks, and laurels - I mean in general aspect, not botanically. The trees are on 'a much larger scale than our own. Palms bulk considerably, sometimes in groves, sometimes in smaller groups. There is great variety in the colouring of the foliage, and the brilliant colours of flowers also occur at some seasons. For instance, there is a magnificent avenue of trees in the Botanic Garden which I formerly mentioned. These trees, about April and May, are covered to their summits with blossoms of a bright salmon colour. Creepers carrying bright-tinted flowers add to the array of colour; but flower-covered trees and creepers occur only at intervals. Many of the trees are deciduous, but, so far as I have observed, there is no winter sleep of the plant, as in temperate climates. As soon as a tree has shed its mature leaves, the fresh young buds are ready to burst forth, so that in about a week the tree is clothed again with fresh verdure. As this sort of fall of the leaf and renovation does not take place at one time, but is going on throughout the year, it adds to the variety of tints in the forest. The varieties of timber hitherto exported have been chiefly the mora and greenheart; but india-rubber trees, and many others producing curious and beautiful timber, and also medicinal plants, grow in great abundance. It is a most impressive sight to look on the outside of a great reach of forest. This, of course, is only possible when there is some sufficient height from which a view of the lower-lying forest can be obtained. I remember one occasion when $I$ had the good fortune to obtain a view of this sort. Standing on the top of a hill which rises in complete isolation upon a level plain, traversed by the Barima river, I looked over an expanse of forest, bounded in one direction by some hilly ridges, hazily, yet sufficiently visible at a distance, as I calculated, of about fifteen to twenty miles, in another direction stretching away, apparently without limit, until it merged in the horizon. I can use no simile so appropriate as an ocean of forest. Even the ocean swell was simulated by the effect of slight irregularities of the ground, whilst the tossing of the tree-tops by the wind in the nearer distances, their bright foliage rising in glistening points of light, produced a semblance of the superficial wavelets.

The mountains of Guiana are so far from the coast, and so difficult of access, that only a few enterprising travellers have visited them. There are two parallel chains running in the direction east to west, the Pacaraima and the Merume mountains. There are other mountains with very unpronounceable names, not equalling in magnitude second-class Scotch mountains. The Pacaraima range culminates in that extraordinary mountain, Roraima, which until recently was believed to be inaccessible. 
This mountain rises 5000 feet above the elevated tableland, and 8609 feet above the sea. The upper part consists of a table-top surmounting a mural precipice, estimated at about 2000 feet high. Schomburgk says: "These stupendous walls are as perpendicular as if erected with a plumb line." Considerable masses of water fall at different points. The Indian songs and traditions are full of allusions to this mountain. They had a tradition that the spirits of the mountain would for ever prohibit its ascent by man. Amongst scientific men there was an idea that on this tableland, cut off as it was from all communication with the world, animal and vegetable forms of primitive type might exist, different from anything known on the ordinary surface. The mystery was dispelled by a successful ascent, made on 18 th December 1884, by $\mathrm{Mr}$. im Thurn, Commissioner of the North-West district of Guiana. Resolved on making a thorough exploration and examining the precipice from different points of vantage, he at length discovered a sort of ledge on the rock by which it was practicable to ascend, and in this way reached the summit, where he was able to remain long enough to make important observations. The primeval forms, however, which it was thought possible o might exist, were not found, but various plants, hitherto undescribed, $\rightarrow$ were collected. A most interesting account of this ascent was published $\ddot{-}$ in a Guiana Journal (Timehri, June 1885). At least three other ascents \# have since been made.

Time will not permit me to say much of the fauna of Guiana. Amongst the animals useful for food are various rodents, such as the labba, accourie, water-haas. Bush-hogs, tapirs, and deer of several varieties are also plenti$\leftarrow$ ful. Amongst beasts of prey the most important are the jaguars and antbears. Monkeys are numerous and of several varieties, and snakes are characteristic and abundant, although from their timid habits less seen \pm than might be expected. They include the camoodie, a species of boa, which has been found thirty feet long, and more than three feet round, the rattlesnake and the deadly labarria, besides many other varieties, $\vec{t}$ the greater proportion of which are not venomous. Insect life abounds, and the country is particularly rich in birds, as many as 1200 varieties having been named, and the list not being complete. Some of the birds are of remarkably beautiful plumage, their bright colours even being a feature sometimes in the landscape. I have seen flocks of flamingoes, of brilliant vermilion colour, circling and poising themselves like rooks amongst the tree-tops on a river bank, and at other times in ordered battalions on their aerial journeys - the older birds in their bright uniforms on the outside of the formation, the young ones in grey undress in the centre. And I remember also seeing in the North-West district flights of parrots, some bright green, others-the large macawsshowing most brilliant hues of blue and yellow.

The climate of Guiana is equable and moderate for a tropical one. There is no such burning heat as is known in the plains of India. The highest marking of a perfectly shaded thermometer is said to be $90^{\circ}$. I do not myself remember to have seen it over $87^{\circ}$ in the course of sixteen years, and very seldom as high as that. In the colder monthsthat is, from December to April or May-it seldom rises above $81^{\circ}$ 
in the shade, and for all purposes of indoor life, as far as sensation is concerned, the temperature is perfect. The lowest range is about $72^{\circ}$ or $71^{\circ}$ between five and six in the morning, and then a feeling of chilliness is produced. But the average minimum is not less than $76^{\circ}$. These are temperatures which occur at the sea coast. In the forests and on the higher grounds the minimum is considerably lower, and the maximum is higher. The comparatively moderate temperature is no doubt due in part to the trade winds, which blow from the north-east with great regularity. They diminish the sensation of heat as much as, or perhaps more than, the actual temperature. The length of the nights is also a mitigating factor. The sun is below the horizon for about twelve hours at the longest day and twelve and a half hours at the shortest. I believe the hothouse at Kew where the Victoria regia is kept - which most of you know very well-is meant to be of the temperature which prevails in a Guiana forest in the lower levels; but the high temperature of the Kew house is much more felt, because we go suddenly into it from the cool air outside, whereas one is gradually introduced to the temperatures of the Tropics.

It is, perhaps, as good a practical test of a climate to observe what. people do, as to study meteorological instruments. It may illustrate the nature of the Guiana climate when I mention that there is a flourishing cricket club at Georgetown. They play matches amongst themselves, and, when opportunity offers, with teams from the West India Islands, and recently have played with an English team. I have never heard of any mischief resulting. Lawn tennis is also a favourite amusement, but it is generally played after four in the afternoon, when the sun's heat is much diminished. It was, and I believe is, a practice for life assurance companies to charge considerably higher rates for Guiana than for temperate climates, and there is a widespread impression, probably not without foundation in most cases, that the climate exercises some strain upon European constitutions, to counterbalance which it is advisable to make occasional visits to cooler countries.

Thunderstorms are frequent at the commencement of the rainy weather, and also, although in a less degree, at its termination. Lightning is very vivid, and is often seen streaming from cloud to cloud without coming to the ground. It has been remarked that few instances have been noticed of injury done either to buildings or to animals. It has been surmised that certain species of palm-trees, which tower to great heights, and have very moist and succulent leaves and stems, act as conductors, but there has been no scientific verification of this. It should also be mentioned, when on the subject of meteorology, that hurricanes, such as those which have from time to time done great mischief in the neighbouring West India Islands, are unknown in Guiana, so far as discoverable from the memory of any inhabitant or from any written record. It would detain you too long were I to enter upon the conjectures by which it has been endeavoured to explain the prevailing immunity.

It is time to say a word as to the industries of the colony. These are named in three words - sugar, gold, and-a long way after-timber. Although the soil is probably capable of growing every product of the 
Tropics, and although other products than sugar are cultivated to a slight extent, sugar has from a variety of causes come to be far and away the most important-indeed, as things are at present, to be the only cultivation of vital importance. In the palmy days of the industry, a sugar estate was as valuable as a gold mine. Not only did the proprietors receive very large revenues from their estates, but their managers and attorneys in the colony-for owners were much addicted, to absenteeism-lived in wealth and luxury. The sugar estates were laid out and cultivated by the Dutch settlers by means of slave labour, and their cultivation was carried on by their British successors by the same instrumentality, until the public conscience of Great Britain rebelled against the system. It is strange nowadays to come face to face, as one does in old newspapers and records of the colony, with the working of a system of slavery. The prædial slaves were, as to their legal status, the appurtenances of the plantation to which they belonged. If the plantation changed owners, the slaves changed their masters. Curious advertisements may be read of lots of slaves for sale, in which their sound health is guaranteed, and their qualifications are described as trained carpenters, blacksmiths, field hands, or otherwise. Even at the present day there are persons living in the colony who were slaves, and some of them regretfully contrast their present circumstances with the older times, when they lived without cares, and were comfortably provided for in old age by their masters as well as when in full strength and vigour. The system was suddenly brought to an end, and there ensued a not altogether unnatural revulsion on the part of many of the new freedmen against steady or hard work in any form. The consequence was that it was difficult to induce them to engage as hired labourers, except at excessive rates of wages. Even on these terms they were not always reliable, and would strike work and hold out for impossible wages at critical periods, as when the crops had reached a stage at which it was of vital importance they should be rapidly reaped. To remedy this state of things a system of bringing East Indians to Guiana as estate labourers was set on foot, which still continues. These immigrants are engaged in India on a system of indenture, under the supervision of the Indian Government, and are taken charge of by a Government department in Guiana upon their arrival there. This department regulates, under local laws, the allocation of the labourers to the plantations, their housing, wages, work, medical care, and other incidents of their position. On completing the term of five years' indenture the immigrant is entitled to a free return passage to India if he chooses to claim it. Many of the immigrants then take their return passages and go back to India, generally carrying with them considerable savings. A good many, after spending some time in India, return to the colony under fresh engagements. Others reindenture in the colony, and others quit the regulation labour and live in the colony on their own responsibility, many finding employment on the plantations. The expense of importing labourers is borne partly by the sugar proprietors; partly by the general community.

Notwithstanding this artificial labour system, the Negro retains his 
position. He is of stronger physique than the East Indian, and preferred for the hardest work. Negroes also, for the most part, fill the more responsible positions in the manufacturing processes, and in managing machinery. Negroes and coloured men have, if not quite a monopoly, yet a very large share of all the handicraft work carried on in the colony, as carpenters, blacksmiths, and the like. They become excellent workmen when properly trained. This is not the time to enter into a discussion of the many-sided Negro question, which is not, nor is likely to become, a pressing one in British Guiana. The Emancipation Acts of half a century ago found the Negroes of Guiana, as well as of the West India Islands, in a condition in which it was scarcely possible for them to derive full benefit from their new-found freedom. The state of subjection which they had been under for centuries, whilst it had obliterated the tribal ideas and organisations of their own country, in which there was much to foster a regard for others and many of the virtues, had supplied very little instead, beyond a certain amount of secured material well-being. There was very little to develop the conscience or intelligence of individuals, much less to raise anything like a high general standard of feeling or opinion. But many agencies of improvement are now at work; it is unquestionable that improvement has set in, and there is good hope for the future. The new industry in gold seeking and collecting in the interior of the country has powerful attractions for a considerable class of Negroes and half-castes, who, although possessed of much desultory energy, are repelled by the monotony of fixed employments. Many of these have benefited in a rational way by the increase of well-being which gold has brought to them, whilst the older sugar industry has been partially disorganised by the competition of the younger one. That difficulty, of course, admits of remedy.

But the sugar industry has a much more serious grievance in the payment by Foreign Governments of bounties to their own people on their exports of beetroot sugar, whilst the importation of Guiana and West India sugar into the beet-producing countries is barred by heavy duties. These bounties operate adversely to our colonial sugar-growers in two ways: directly, they enable the grower of beetroot sugar to under-sell the colonial grower in the market; indirectly, by stimulating the over-production of beet sugar in foreign countries, they drag down the ruling average of price to a level at which it ceases to be remunerative. Much of this bounty-fed sugar finds its way to Great Britain, and while it reduces in the meantime the market price of sugar, it has inflicted great injury on all who are interested in the production of sugar in the colonies. Instead of the plantations producing large profits, many have been found unworkable except at a loss, and have been abandoned to become wilderness; whilst even as regards the plantations most favourably placed as to soil and situation, it is a most anxious question to those whose fortunes are at stake whether any margin is left at all after paying the expenses, which, under any circumstances, are very heavy. The proprietors and their managers seem to have done all that manly endeavour and skill can do to maintain their position, by improved methods of cultivation, by improved methods and machinery of manufacture, and by 
retrenching expenses in all possible directions. There are some indications that the bounty-paying countries may grow tired of a system in which they tax their own citizens in order that sugar may be sold cheaply to foreigners. Time will show.

As to gold I shall not say much. In 1884 the export notified to the Customs was 250 ounces; in 1888 it was 14,570 ounces; in 1895 it was 122,935 ounces. There is no doubt that gold exists over a large part of the colony. Hitherto it has chiefly been found on the Essequebo river and its tributaries, and to the northward and westward. But the practical problem is to find gold in any given locality in sufficient richness of deposit to give remunerative results. It must be remembered that great expense is incurred in conveying the labourers to the spot, as also their food, and all tools and machinery. Every requisite must be conveyed by boat carriage on the rivers, and then by manual labour, through paths that often must be cut through the forest. In some places-notably on the Essequebo, Potaro, Cuyuni, and Barima rivers and their tributaries-gold has been found in paying quantities, but the deposits successfully worked have been alluvial; and such deposits in the course of continued working become exllausted. Those who have been successful in the industry have had the good fortune to find fresh deposits when the earlier ones were no longer profitable. How long this may continue is a question on which even experts hesitate to give an opinion. There are, it is said, veins of quartz rich in gold in some places, and at least one company is or will be engaged in quartz crushing. I have, however, no recent information as to the result.

In concluding this sketch I may inform you that the exports of Guiana in the year $1893-94$ were of the total value of $£ 2,358,917$, and the imports were of the value of $\mathfrak{£} 1,920,715$. The public revenue from

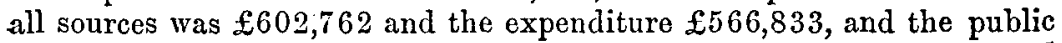
debt was of the respectable amount of $£ 867,875$. The colony, you will have perceived, has great possibilities, and its value may well be deemed to lie rather in its resources than in their actual present development. ${ }^{1}$

\section{ARABIA AND ABYSSINIA IN ANCIENT TIMES.}

\section{By J. W. M'CRIndLe, M.A., M.R.A.S.}

THE author of the work noted below ${ }^{2}$ has made the early history of Arabia his special study. He has frequently travelled in that country, and made himself familiar with its language, and with its old records and monuments, which throw light on its past before Islam had as yet arisen. The first fruits of his researches he published in 1890, in a twovolume work, entitled Sketches of the History and Geography of Arabia from

I The remainder of this paper related to the dispute as to the boundary between British Guiana and Venezuela, in which the United States has interfered, and is not deemed suitable for this journal. - ED.

2 Die Abessinier in Arabien und Afrika, von Dr. Eduard Glaser. München, 1895. 